deal with theory, experimental technique or special subjects (soaps, dyestuffs, silicates, proteins, and so on). The papers, which will be available in advance, will be taken as read; each author will indicate a few points of special interest, after which the subject will be open for discussion. Among those outside Great Britain who are contributing papers are Dr. E. J. Bigwood (Brussels), Prof. P. Debye (Leipzig), Prof. E. Elod (Karlsruhe), Prof. A. Frumkin, Dr. Proskarnin and Prof. A. J. Rabinovith (Moseow), Prof. E. Hammarsten (Stockholm), Prof. H. R. Kruyt (Utrecht), Prof. Linderstrom-Lang (Copenhagen), Prof. A. Lottermoser (Dresden), Prof. J. W. McBain, Mrs. M. E. Laing McBain and Margaret M. Barker (Stanford University), Prof. W. Pauli (Vienna), Prof. M. Sameč (Ljubljana), Prof. A. Treadwell (Zurich) and Dr. F. Valko (Ludwigshafen a/Rh.).

\section{Annals of the Transvaal Museum}

THe Committee of the Transvaal Museum has just published, through the Cambridge University Press, indexes to all the volumes of the Annals from vol. 6 (1917-20) to vol. $11(1924-26)$. The indexes are thorough guides to the systematic contents of the volumes, and show new genera, subgenera, species, subspecies and the main reference in heavy-faced type. But they do not contain authors' names or titles of papers contained in the volumes.

\section{Announcements}

The Lord President of the Council has appointed Mr. E. Barnard to be director of food investigation in the Department of Scientific and Industrial Research, and Dr. F. Kidd to be superintendent of the Low Temperature Research Station, Cambridge. Both these posts were previously held by the late Sir William Hardy. Mr. Barnard has been assistant director of food investigation since 1931. He joined the Department of Scientific and Industrial Research on entering the Civil Service in 1919. Dr. Kidd, who has been on the staff of the Low Temperature Research Station since its establishment in 1922, has been engaged on food investigation work in the Department since 1918.

Dr. Minoru Mashrno, a research chemist in the Tokyo Imperial Industrial Research Laboratory, has been awarded the medal for "special merit in research" of the Society of Chemical Industry, Japan. For many years, Dr. Mashino has made valuable investigations on the proteins of the soya bean.

The Engineer's German Circle has arranged a tour of Germany to be held on August 30-September 7. Several places of technical interest will be visited. Further information can be obtained from the Amerop Travel Service Inc., 66, Haymarket, London, S.W.1.

IN a pamphlet of 30 pages, entitled "Practical Physiology of the Sense Organs", Dr. R. J. Lythgoe has aimed at collecting under one cover all the profitable exercises to be found in a scattered literature (Oxford University Press. London: Humphrey
Milford, 1934. 1s, net). The author describes simple experiments on the sense organs which need a minimum of apparatus and preparation. The descriptions are as brief as possible, and are supplementary to the material found in theoretical textbooks. The total time required for the course is about 12 hours.

Messrs. Bernard Quaritch, Ltid, 11, Grafton Street, London, W.1, have issued Catalogue No. 489, "A Catalogue of Books and Periodicals on Aeronautics, Astronomy, Chemistry, Electricity, Engineering, Fortification and Gunnery, Horology, Mathematics, Meteorology, Mining and Minerals, Navigation, Physics, Pyrotechnics, Surveying, etc." This contains nearly 600 items. It includes many scarce and important early works on the mathematical and physical sciences, among which may be mentioned a first edition of Newton's "Principia"; the first English translation of Euclid's "Elements"; and early treatises on magnetism, by Peregrinus, Barlow and others. A number of valuable sets and long runs of important scientific periodicals are offered. These include the Philosophical Transactions of the Royal Society, complete and unabridged from the commencement in 1665 to 1933 .

Applications are invited for the following appointments, on or before the dates mentioned:-An assistant lecturer in mechanical engineering at the Harris Institute, Preston--The Principal (July 24). A lecturer in chemistry at the Leeds College of Technology-Director of Education, Leeds (July 24). A lecturer in electrical technology and power at the Municipal College, Burnley-Director of Education, Burnley (July 25). A principal of the Municipal Technical School, St. Helens-Education Officer, St. Helens (July 27). An assistant (Grade II) in the Admiralty technical pool for duty at the Admiralty Compass Department at Slough-Secretary of the Admiralty (C.E. Branch), London, S.W.1 (July 28). Eleven surveyors of works in the Military Engineer Services Establishment, India-The Under-Secretary of State for India, Mílitary Department, India Office (July 28). Two assistant marketing officers in the Ministry of Agriculture and Fisheries-Secretary (July 30). An instructor in the Navigation Depart. ment, Merchant Venturers' Technical College, Bristol --Principal (July 30). A lecturer in mechanical engineering at the Municipal Technical College, Hull-Director of Education, Hull (Aug. 1). A lecturer in mechanical engineering at the Municipal Technical College, Hull-Director of Education, Guildhall, Hull (Aug. 1). A principal of the Carlisle Technical School-Director of Education, Carlisle (Aug. 8). A principal of the Widnes Municipal Technical College-Secretary, Education Office, Town Hall, Widnes (Aug. 31). A reader in industrial hygiene and medicine in the University of Birmingham-Secretary (Sept. 1). Fulltime appointments in engineering subjects at the County Technical College, Mansfield, NottsThe Principal. A mechanical draughtsman on the Singapore Harbour Board-Crown Agents for the Colonies, 4 Millbank, London, S.W.1, quoting M/3446. 